\title{
Explicitation in the Kalatidha Translation by Kamajaya
}

\author{
Supana $^{1}$; Sutarjo ${ }^{2}$; Endang Tri Winarni ${ }^{3}$ \\ \{1Supana_77@staff.uns.ac.id, ${ }^{2}$ sutarjojawa_1160@staff.uns.ac.id, ${ }^{3}$ ending_tw@staff.uns.ac.id,\} \\ 123 Universitas Sebelas Maret
}

\begin{abstract}
Kalatidha by R.Ng. Ranggawarsita was written in the form of traditional Javanese poetry called tembangmacapat (song of Macapat). This form of poetry has fixed rules, including a certain number of lines in each stanza, a certain number of syllables per line, and a certain rhyme.This strict rules result a lot of deletions in literary works in the form of poetry of this type.Meanwhile, due to the demands of translation which must have a high level of readability, the explicitation in the translation of works in the form of song is inevitable.This research reveals the explicitation in the Kalatidha translation translated by Kamajaya.This research used a descriptive qualitative strategy.Data in the form of explicitation contained in Kalatidha were collected using content analysis techniques.It used interactive analysis model to analyze the data.The result of this study indicates that the explicitation in the Kalatidha translation including various sentence elements, including subjects, predicates, objects, complement, description (Ds) and conjunctions.Object explicitaion occurs 11 times, predicate 7 times, subject 6 times, complement 5 times and description deletion only once.The explicitations of conjunction are as much as 20 times consisting of causal conjunctions 10 times, additive 4 times, adversative 3 times, and temporal 3 times.Through number of explicitations show that many elements of the sentence structure in the text in the form of tembangmacapat (song of Macapat) which was deleted.In that translation, the elements that are deleted need to be explicited so that the meaning can be better understood by readers of the translation well.
\end{abstract}

Keywords: translation, Kalatidha, explicitation

\section{Introduction}

The poet R.Ng. Ranggawarsita was an important figure in the renaissance of Javanese literary literature in the XVIII-XIX centuries.He was known by the public society as a closing poet and had created around 70 pieces of work covering various fields, such as philosophy, chronicle (history), term (prophecy), genealogy, education, science, puppetry, and lexicography[1].Work of R.Ng. Ranggawarsita, especially Kalatidha, was widely discussed in various seminar opportunities by experts both at national and international. Florida [2], for example, discussed the life of the Poet Ranggawarsita in the Simposium International XIV Masyarakat Pernaskahan Nusantara in Yogyakarta (the XIV International Symposium on the 
Archipelagic Society in Yogyakarta).In discussing Ranggawarsita's life, Kalatidha, one of Ranggawarsita's works, is the subject of her discussion.Supana [3]also discussed the contents of Kalatidha specifically the cause of social chaos and its solution in a seminar discussing Kalatidha held in UNS Surakarta.

Works of Ranggawarsita are also written into books.One of the books that specifically presents the works of Poet Ranggawarsita along with its translation is a book titled "Lima Karya Pujangga Ranggawarsita" (Five Works of Poet Ranggawarsita) written by Kamajaya and published by Balai Pustaka, Jakarta, 1991.The five works of Ranggawarsita contained in the book are 1) Serat Kalatidha, 2) Serat Sabdajati, 3) Serat Sabdatama, 4) Serat Jaka Lodhang, and 5) Serat Wedharaga [4].Those five works of poet Ranggawarsita which were written is accompanied by translation. The translation of Ranggawarsita's work by Kamajaya, especially Kalatidha, will be the object of this research.

The poet Ranggawarsita's work was written in the form of a traditional Javanese poem called tembang macapat (song of macapat). There are 9 types of poetry of tembang macapat, namely dhandhanggula, sinom, kinanthi, pangkur, gambuh, megatruh, pucung, mijil, and maskumambang. Each type of these songs has a certain convention related to the number of lines per stanza (guru gatra), the number of syllables in each row (guru wilangan), and the final sound of each line (guru lagu).In order to fulfill the convention, language compaction often occurs in composing lyrics of macapat song. This compaction causes a separate problem in translation because there are many implications or implies of meaning. To divert messages in the source language into the target language correctly and can be understood by the reader, the translator must use certain strategies. The strategy that is widely used in the translation is explicitation, which expresses the implicit meaning contained in the source text into the target text.Blum Kulka [5] based on his observation of translations from English into French and vice versa shows that the tendency of explicitation in translation is very high and inevitable.Explicitation in translation (since it is done by adding linguistic elements such as words, phrases and clauses) has a potential to change the meaning between the source language text and the target language text. Changes in meaning in the translation will affect the quality of the translation because the translation principally must maintain the equivalence of meaning and equivalence of language style[6],[7].Although the equivalence of meaning does not mean an absolute equivalence [8].Based on these thoughts it is necessary to disclose the explicitation contained in the Kalatidha translation and the background of its explicitation.

Explicitation in translation occurs when a translation realizes more explicit meanings than the source text.In other words, the translated text is more explicit than the source text [9].In a text, for various reasons, many elements of the text are often implied, referring that it is not realized in the grammar contained in the text.Grammatical elements that are not realized can be in the form of Subject $(\mathrm{S})$, predicate $(\mathrm{P})$, object $(\mathrm{O})$, complement $(\mathrm{Cl})$, description $(\mathrm{Ds})$, and so forth.These implied elements are often explicited in translation.Molina called the explicitation in this translation as the amplification technique, a translation technique that expliciting or paraphrasing an implicit information in the source language [10].

\section{Research Method}

This research is descriptive qualitative research that seeks to explore qualitative data and describe the results of research in a thorough, detailed and nuanced manner[11].The data in this study are the explicitation in the translation of the Serat Kalatidha of Ranggawarsita by Kamajaya.The data source is Kalatidha and the translation contained in the book titled "Lima 
Karya Pujangga Ranggawarsita" (Five Works of Poet Ranggawarsita) published by BalaiPustaka in 1991 by Kamajaya.Data collection techniques used content analysis that is collecting research data sourced from documents [12].Data analysis which is used is an interactive model analysis of the three components of the analysis namely data reduction, data presentation, and drawing conclusions or verification [13]. The activities were carried out in an interactive form with the process of collecting data as a cycle process "three components of analysis are data reduction, data presentation, and drawing conclusions or verification, the activities carried out in an interactive form with the process of collecting data as a cycle proces[14].

\section{Results And Discussion}

The lines in the song are basically a series of sentences.One sentence in the song is often more than one line.In the Kalatidha translation, explicitation occurs in various sentence elements. There are five sentence structure elements or sentence constituents according to Sudaryanta based on syntactic functions, namely the predicate $(\mathrm{P})$, subject $(\mathrm{S})$, object $(\mathrm{O})$, complement $(\mathrm{Cl})$, and description (Ds) [15].In the translation of Kalatidha there is explicitation in the form of $\mathrm{S}, \mathrm{P}, \mathrm{O}, \mathrm{Cl}$, Ds.

Subject explicitation occurs 6 times.Element subjects of the sentence that are made explicitly in words: Ranggawarsita, orang (the person), sang pujangga (the poet), ceritaitu (the story), orang yang sudahsentosaitu (the person who has been tranquil), and ia (he or she).The following table shows the words that are explicated and the location of the verse and line where the explicitation occurs.

\begin{tabular}{lll}
\hline \multicolumn{2}{l}{ Subject Explicitation } & \\
No & Explicited Sentence Element & Stanza/line \\
\hline 1 & Ranggawarsita & $1 / 6$ \\
2 & Orang (the person) & $5 / 5$ \\
3 & Sang pujangga (the poet) & $5 / 9$ \\
4 & Ceritaitu (the story) & $6 / 1$ \\
5 & Ia (he or she) & $9 / 4$ \\
6 & Orang yang sudah sentosa itu (the person who has been & $9 / 9$ \\
& tranquil) & \\
\hline
\end{tabular}

The predicate element which is explicited in words: merasa (feeling), mengetahui (knowing), mempunyai (possessing), menjadi (becoming), memahami (understanding), menggila (crazy), menjauhkan (distancing), memohon (pleading), and katanya yang pujangga (his poetical words). The following table shows the words as explicited predicates and the location of the stanza and line which occurs the explicitation.

\begin{tabular}{lll}
\hline \multicolumn{2}{l}{ Predicate Explicitation } & \\
No & Explicited Sentence Element & Stanza/line \\
\hline 1 & Merasa(feeling) & $1 / 7$ \\
2 & Mengetahui(knowing) & $1 / 9$ \\
3 & Katanya yang pujangga(his poetical words) & $4 / 3$ \\
4 & Menjadi(becoming) & $5 / 4$ \\
5 & Memahami(understanding) & $6 / 7$ \\
6 & Menggila(crazy) & $7 / 4$ \\
7 & Memohon(pleading) & $12 / 9$ \\
\hline
\end{tabular}


Most explicitation occurred in the Object sentence element, which numbered 11 cases.Words as object explicitation sentence are Ki Pujangga, pembesar(prominent person), kitab(holy book), usaha(effort), jalan(pathway), sang pujangga(poet).

\begin{tabular}{lll}
\hline \multicolumn{2}{l}{ Object Explicitation } & \\
No & Expicited Sentence Element & Stanza/line \\
1 & Ki pujangga (the poet) & $3 / 5$ \\
2 & Ki pujangga (the poet) & $3 / 9$ \\
3 & Pembesar (prominent person) & $4 / 4$ \\
4 & Pembesar (prominent persont) & $4 / 5$ \\
5 & Kitab (holy book) & $5 / 1$ \\
6 & Ki pujangga (the poet) & $8 / 4$ \\
7 & Ia (he or she) & $9 / 1$ \\
8 & Usaha (effort) & $10 / 1$ \\
9 & Jalan (pathway) & $10 / 6$ \\
10 & Sang pujangga (the poet) & $11 / 6$ \\
11 & Sang pujangga (the poet) & $11 / 9$ \\
\hline
\end{tabular}

The explcited complement elements are in the words: Ki Pujangga(poet), orang (person), dari yang demikian(from that circumstance), lahirbatinnya(its physically and spiritually), Menjauhkan diri dari keduniawian (keeping away from worldliness).

\begin{tabular}{lll}
\hline \multicolumn{2}{l}{ Complement Explicitation } & \\
No & Explicited Sentence Element & Stanza/line \\
1. & Ki pujangga (poet) & $3 / 4$ \\
2. & Orang (person) & $7 / 8$ \\
3. & Dari yang demikian (from that circumstance) & $8 / 6$ \\
4. & Menjauhkan diri dari keduniawian (keeping & $8 / 8$ \\
& away from worldliness) & \\
5. & Lahir batinnya (its physically and spiritually) & $9 / 1$ \\
\hline
\end{tabular}

Meanwhile, the explicited description element is kepada Tuhan (for God).In Kalatidha translation there are also many explicitation of conjunctions. Conjunction according to Baker [16] is the use of formal markers to connect sentences, clauses, and paragraphs with one another. Halliday \& Hasan [17] divided conjunctions into four, namely additive, adversative, causal, and temporal. There are 22 conjunction explicitations in the translation of Kalatidha. It consists 11 causal explicitations, 6 additive explicitations, 3 adversative explicitations and 2 temporal explicitations.

\begin{tabular}{lll}
\hline \multicolumn{2}{l}{ Causal Conjunction Explicitation } & \\
No & Explicited Sentence Element & Stanza/line \\
\hline 1 & Sebab (because) & $1 / 3$ \\
2 & Maka (so) & $1 / 6$ \\
3 & Karena (because) & $1 / 9$ \\
4 & Maka (so) & $3 / 1$ \\
5 & Karena (because) & $3 / 3$ \\
6 & Karena (because) & $3 / 9$ \\
7 & Maka (so) & $5 / 6$ \\
8 & Maka (so) & $8 / 4$ \\
9 & Dari yang demikian (from that circumstance) & $8 / 6$ \\
10 & Sebab (because) & $8 / 7$ \\
11 & Sehingga (so that) & $12 / 7$ \\
\hline
\end{tabular}


Conjunctions as explicited causal conjunction are sebab (because), karena (because), maka (so), tetapi (but), untuk (for), lalu (then), tidak lain tentu (eventhough), niscaya (certainly), untuk(for), baik (whether), tentang (about), mungkin (probably), dari yang demikian (from that circumstance), sehingga (so that).

\begin{tabular}{lll}
\hline \multicolumn{2}{l}{ Additive Conjunction Explicitation } & \\
No & Explicited Sentence Element & Stanza/line \\
\hline 1. & Tidak lain tentu (eventhough) & $4 / 7$ \\
2. & Niscaya (certainly) & $4 / 9$ \\
3. & Untuk (for) & $6 / 2$ \\
4. & Baik... tentang (even... about) & $6 / 5$ \\
\hline
\end{tabular}

Additive conjunction explicitations are in the words: untuk (for), tidak lain tidak tentu (eventhough), niscaya (certainly), baik... tentang (even... about), yang (that), ialah (namely).

\begin{tabular}{lll}
\hline \multicolumn{2}{l}{ Adversative Conjunction Explicitation } & \\
No & Explicited Sentence Element & Stanza/line \\
\hline 1 & Tetapi & $3 / 6$ \\
2 & Tetapi & $4 / 4$ \\
3 & Tetapi & $7 / 7$ \\
\hline
\end{tabular}

Conjunction as adversative conjunction explicitation is tetapi(but). Meanwhile temporal explicitations are lalu (then) and akan (regarding).

\begin{tabular}{lll}
\hline \multicolumn{2}{l}{ Temporal Conjunction Explicitation } & \\
No & Explicited Sentence Element & Stanza/line \\
\hline 1 & Lalu & $6 / 8$ \\
2 & Akan & $7 / 5$ \\
3 & Lalu & $8 / 7$ \\
\hline
\end{tabular}

Explicitation in the Kalathidha translation includes various sentence elements, including subject, predicate, object, description, and complement.Conjunction is also a sentence element that is widely explicited.The object of the sentence which is the most explicitation, is 11 cases.In a row, the explicited sentence elements are 7 predicates, 6 subjects, 5 complement, and one case of description. In total, 30 elements are used as explicited sentence functions.Meanwhile there are 20 conjunction explicitations.There are 10 explicited causal conjunction, 4 explicited additive conjunction then explicited adversative and temporal conjunction are 3 for each. Explicitation that occurs shows that the source text which is tembang macapat (macapatsong) is denser than its translation. Blumka [5] also discloses that translated text is longer than source text. The tendency of the translated text which is longer than the source text is due to the existence of terms in the source text that are not contained in the target text or the addition of an explanation in order the translation becomes easier to understand its meaning. For example, this is the translation of the stanza four.

\begin{tabular}{ll}
\hline$\ldots$ & $\ldots$ \\
Pedah apa aneng ngayun & Apakah gunanya di muka (menjadi pembesar) \\
$\ldots$ & $\ldots$ \\
\hline
\end{tabular}

The phrase aneng ngayun that is translated into "di muka" means pembesar (prominent person, or government officials). If in its translated version, di mukais not complemented term "menjadi pembesar" so the reader cannot understand thoroughly. Since phrase di muka in target language is less prevalent as pembesar (prominent person). The length of the Kalatidha translation text from the source is increased due to the existence of explicitation. Explicitation 
of $\mathrm{S}, \mathrm{P}, \mathrm{O}, \mathrm{Cl}$ and Ds that occurs mostly in translation is caused by the source text in the form of poetry which has certain rules. The rules regarding the number of certain syllables in each line cause deletion in the source text. This deletion is explicited in the translation. For example, this is the translation of stanza six.

\begin{tabular}{ll}
\hline Keni kinarya darsana & (Cerita itu) dapat dipakai teladan \\
Panglimbang ala dan becik & Untuk membanding-bandingkan yang buruk dan yang baik \\
... & $\ldots$ \\
\hline
\end{tabular}

From that example above, phrase "cerita itu" (that story) as S is an explicitation due to no deletion in the source text. "Cerita itu" refers to a book of Panitisastra mentioned in the previous section. That deletion ensues due to the required number of syllables in the line, which must be 8 syllables. The deleted element of $\mathrm{S}, \mathrm{P}, \mathrm{O}$ and $\mathrm{Cl}$ in source text is able to be analyzed in its text.In translation, the complement explicitation occurs in the stanza eight.

\begin{tabular}{ll}
\hline$\ldots$ & $\ldots$ \\
Bener ingkang ngarani & (maka) benarlah yang menerka (Ki pujangga ingin menjadi pembesar) \\
Nanging sajroning batin & Tetapi di dalam hatinya \\
Sajatine nyamut-nyamut & Sesungguhnya jauh sekali (dari yang demikian itu) \\
$\ldots$ & $\ldots$
\end{tabular}

In that translation, there is an explicitation in phrase "dari yang demikianitu" (from that circumstance).This phrase is a sentence's complement referring to "ingin menjadi pembesar" (eagerness to be a prominent person) like in the previous section. Explicitation in translation is also in the form of description of sentence element whether in S, P, O and Cl.As an example that is a translation of first stanza.

\begin{tabular}{ll}
\hline Source Text & Translation \\
Mangkya darajating praja & Sekarang martabat Negara \\
Kawuryan wus sunya ruri & Tampak telah sunyi sepi \\
Rurah pangrehing ukara & (sebab) rusak pelaksanaan peraturannya \\
Karana tanpa palupi & Karena tanpa teladan \\
Ponang parameng kawi & Maka sang pujangga (Ranggawarsita) \\
... & ... \\
\hline
\end{tabular}

In the translation of line five, there is explicitation of word "Ranggawarsita".This explicitation is to clarify the sentence subject in that line which is pujangga (poet).There are many people who occupy positions as poets in the Surakarta kingdom, one of them is Ranggawarsita.The poet referred in the source text is Ranggawarsita.Through this explicitation, the meaning of pujangga in the text becomes clear.

The explicitation of element $\mathrm{S}, \mathrm{P}, \mathrm{O} \mathrm{Cl}$ can be studied in other part of the text.The complement explicitation in Kalatidha translation is translator's interpretation.As an example, there is a translation of stanza three.

\begin{tabular}{ll}
\hline Katetangi tangisira & (maka) bangkitlah tangisnya \\
Sira sang parameng kawi & Beliau sang pujangga \\
Kawilet ing tyas duhkita & (karena) tertimpa rasa malu (kepada Tuhan) \\
Katamaning reh wirangi & ...
\end{tabular}

In that translation, there is an explicitation in phrase "kepada Tuhan" that is sentence description.This explicitation is translator's interpretation. If searched in text, it is difficult to find its references. The explicitation of phrase "kepada Tuhan" is translator's interpretation. Another interpretation can also be proposed, such as "kepadas esamanya". 
Besides the explicitation of sentence function elements in $\mathrm{S}, \mathrm{P}, \mathrm{O}, \mathrm{Cl}$ and Ds in Kalatidha translation, there happens many conjunction explicitations involving causal, additive, temporal and adservative conjunctions. This conjunction explcitation is to explain the correlation between sentences. For example there is a translation of stanza twelve.

\begin{tabular}{ll}
\hline$\ldots$ & $\ldots$ \\
Sanityasa amematuh & Selalu mensucikan hati \\
Badharing sapudhendha & (sehingga) urunglah siksaan Tuhan
\end{tabular}

In that translation there is conjunction explicitation in word "sehingga" (so).Through this explicitation, the interalimatic relation becomes definite. The interalimatic relation in translation is a causal relation, the meaning of sentence "urunglah siksaan Tuhan" (taking off from God's torture) as a consequence from sentence "selalu mensucikan diri" (always purifying yourself). Explicitation in the poet translation of tembang macapat is exceptionally high. Almost in each stanza of Kalatidha translation, explicitation occurs in S, P, O, Cl, Ds and conjunction. This is inseparable from the literary Kalatidha which has strict rules, especially in the number of syllables per line and the number of lines in each stanza. As a literature work, the interalimatic relation and its stanza is implicit. It is due the poetry only conveys the core of idea or thought, the unimportant thing is left behind[18]. The language dense implication of this poetry is the occurrence probability of explicitation in translation as appeared in Kalatidha translation. The rules that must be fulfilled in the number of lines and syllables in each line make the poet often condense the sentence so there are many parts of sentence which are deleted.In order to understand the contents of the text in the form of tembang macapat, the reader must be able to interpret the parts of the text that are obscured. Likewise in translation, in order the content of the translated text can be understood by the reader, the elements that are obscured in the text must be explicited in the translation.

\section{Conclusion}

The explicitation in Kalatidha translation involves certain elements, among others $\mathrm{S}, \mathrm{P}, \mathrm{O}$, $\mathrm{Cl}$, Ds and conjunction. As a literary work, Kalatidha expresses things that are considered important and leaves out the words that are considered unnecessary in expressing ideas.In addition, the regulator and differentiator of tembang macapat with immensely strict rules, which is used in Kalatidha, force the author to use words in such a way as to fulfill the demands of the rules in song.The obscuring of linguistic elements in song often occurs as a strategy to fulfill the rules in song. Meanwhile, in order the reader can understand the translation easily, the obscured elements in the source text are important to be explicited so that the sentences in the song can be captured in their entirety and the interalimatic relation becomes clearer.

\section{References}

[1] A. Tedjowirawan, "Menelusuri Kebesaran Pujangga R.Ng. Ranggawarsita Melalui KaryaKaryanya." FIB UGM, Yogyakarta, p. 62, 2009.

[2] N. K. Florida, "Titik-Titik Terakhir Pujongga Penutup: Jaman Edannya Ronggawarsita di Surakarta pada Akhir Tahun 1873.” Masyarakat Naskah Nusantara (MANASSA), Yogyakarta, 
pp. $1-4,2012$.

[3] Supana, Kalatida: Jaman Edan dan solusinya:Kajian Mutakhir Bahasa, Sastra, danBudaya Daerah untuk Membangun Kebhinekatunggalikaan Negara KesatuanRepublik Indonesia. Surakarta: Program StudiSastra Daerah, Fakultas Ilmu Budaya, UniversitasSebelasMaret, 2017.

[4] Kamajaya, "Lima Karya Pujangga Ranggawarsita." Balai Pustaka, Jakarta, pp. 20-113, 1991.

[5] Shoshana Blum-Kulka, "'Shift of Cohesion and Coherence in Translation'. Translation Studies Render (ed).” Routledge, London, p. 301, 2000, doi: - .

[6] E. A. Nida, "Towards a Science of Translati0n.” E.J. Brill, Leiden, 1964.

[7] L. L. Mildred, Meaning Based-Translation: A Guide to Cross-Languange equivalences. Maryland: University Press of America, 1998.

[8] A. Pym, "Natural and directional equivalence in theories of translation," vol. 2, pp. 271-294, 2007.

[9] S. Hansen-schirra, S. Neumann, E. Steiner, and J. G. Mainz, "Cohesive explicitness and explicitation in an English-German translation corpus *," vol. 2, pp. 241-265, 2007.

[10] L. Molina and A. H. Albir, "Translation techniques revisited: A dynamic and functionalist approach," Meta, vol. 47, no. 4, pp. 498-512, 2002, doi: 10.7202/008033ar.

[11] H. B. Sutopo, "Metodologi Penelitian Kualitatif: Dasar Teori dan Terapannya dalam Penelitian." UNS Press, Surakarta, pp. 62-63, 118-120, 2006.

[12] R.K.Yin, "Case study research: Design and methods." Sage Publications, Beverly Hills, CA, p. 57, 1987, doi: -.

[13] S. T. Widodo and K. Saddhono, "Petangan Tradition In Javanese Personal Naming Practice: An Ethnoliguistic Study," GEMA Online ${ }^{\circledR}$ J. Lang. Stud., vol. 12, no. 4, 2012.

[14] A. Miles, M., \& Huberman, Qualitative Data Analysis. London: SAGE Publications., 1992.

[15] et all Sudaryanto, "Tata Bahasa Baku BahasaJawa." Duta Wacana University Press, Yogyakarta, p. 62, 1992.

[16] M. Baker, In Other Words: A coursebook on translation, Second edition. .

[17] R. H. M. A. K. Halliday, "Cohesion in English.” Oxford University Press., London, pp. 1-6, 1976.

[18] R. D. Pradopo, "Semiotika: Teori, Metode, dan Penerapannya dalam Pemaknaan Sastra." Humaniora N0. 10 April 1999, Yogyakarta, p. 80, 1999. 